\title{
THE AUSTRALIAN UNIVERSITIES COMMISSION
}

$\mathrm{T}$

HE second report of the Australian Universities Commission* covers the 1961-63 triennium and the Commission's recommendations for the triennium 1964-66, for the first two years of which the rapid growth in numbers of students which marked the 1961-63 triennium is expected to continue. The report covers 10 universities, including the Australian National Institute of Advanced Studies and Sohool of General Studies, both founded in 1946. Total enrolments of students increased from 53,391 in 1960 to 68,949 in 1963 and a total of 94,650 is forecast for 1966; the number of equivalent full-time students is given as $41,164,52,225$, and 73,740 respectively; and of full-time staff, $3,849,4,748$, and 6,704 , the two latter figures assuming a student/staff ratio of $11: 1$. Recommended grants for the 1961-63 triennium totalled $£ 124.8$ million. During the triennium, establishment of new university colleges at Townsville and Wollongong was supported, as well as a new university institution at Bedford Park, Adelaide (Nature, 201, 553; 1964), and a new technological institution at Whyalla. During the 1964-66 triennium, establishment of further university institutions in the Sydney and Melbourne areas is recommended, together with a university college at Newcastle.

Of 51,395 students enrolled for bachelor degrees in $1962,8,420$ were in science, 5,144 in medicine, 6,107 in engineering and 14,979 in arts. About two-thirds of fulltime students appear to receive some form of assistance from public funds. There has been a steady increase in postgraduate students since 1957 , from 1,357 , or 3.69 per cent of the total enrolment to 3,691 or $5 \cdot 64$ per cent, in 1962 , and the figure is expected to reach 6,900 in 1966 . Sponsored overseas students numbered 1,146 at June 30, 1962 , and the total of overseas students in 1962 was 3,895 , or 6 per cent of enrolments. Of estimated full-time academic staff in State universities in 1963, 391 were professors, 365 readers, 1,149 senior lecturers, and 1,529 lecturers. The ratio of academic staff to students varies widely for faculties, and the report indicates that recruitment of high-calibre staff presents the same problem as in the United Kingdom.

As in the preceding triennium, a notable feature of the 1961-63 triennium was the growth of the research programmes and postgraduate schools of the Australian universities. Enrolments for Masters' degrees increased

- Commonwealth of Australia. Australian Universities, 1961-1966: Second Report of the Australian Universities Commission. Pp. ix $+124+$ from 2,048 in 1961 to 2,493 in 1962 and 3,040 in 1963 , and are expected to reach 4,283 in 1966 ; for Ph.D. degrees, the corresponding figures are $1,092,1,341,1,620$ and 2,572. Expenditure on research in Australian universities rose from $£ 3,048,617$ in 1959 to $£ 3,610,564$ in 1960 and $£ 5,204,831$ in 1961. Of the last-mentioned total, $38 \cdot 8$ per cent was in biological (including medical and dental) sciences, 40.4 per cent in physical sciences, $5 \cdot 6$ per cent in technology and applied science, and $12 \cdot 3$ per cent in social sciences. Of the 1961 total $£ 2,041,915$ was from external sources.

A separate chapter in the report deseribes the spectacular advance in the development of electronic data processing equipment for scientific purposes. Two committees were appointed to deal with this field in 1960 ; one was a policy committee to co-ordinate the installation of computers for Commonwealth of Australia organizations and universities; the other was an expert interdepartmental committee to co-ordinate computing activities in Government departments and agencies. For the 1961-63 triennium, the Australian University Commission offered grants up to $£ 30,000$ to universities without computers for installing modest facilities out of an approved capital research equipment grant of $£ 1$ million; and for the 1964-66 triennium, grants totalling $£ 948,000$ have been recommended. Including a Commonwealth grant of $£ 1$ million, it is estimated that more than $£ 2.8$ million was spent in 1961-63 on affiliated residential colleges and about $£ 1.5$ million on halls of residence, and at the end of the triennium $14 \cdot 3$ per cent of the students were in residence. For the 1964-66 period, grants totalling $£ 1.2$ million for affiliated residential colleges and $£ 3,463,000$ for halls of residence are recommended, and at the end of the triennium the proportion of students in residence is expected to rise to 16-17 per cent. For the 1964-66 period, grants totalling $£ 172$ million are recommended, of which $£ 81.4$ million is from the Commonwealth and $£ 90.6$ million from the States. Of the total, $£ 123$ million is in recurrent grants and $£ 39$ million in capital grants. The report gives considerably greater detail of recommended grants for each university institution than is customary in the quinquennial reports of the University Grants Committee in Britain. There are also illustrations, and among several appendixes are the report of the Committee on University Salaries, a note on the computer network for the Commonwealth of Australia and some designs for halls of residence, in which the cost of now places is estimated at $£ 2,000$ per place.

\section{PHYSIOLOGY, ECOLOGY AND BIOCHEMISTRY OF GERMINATION}

A $\mathrm{N}$ international symposium on "Physiology, Ecology and Biochemistry of Germination", organized by Prof. H. Borriss to mark the two-hundredth anniversary of the Botanic Gardens of the Ernst-Moritz-ArndtUniversity at Greifswald, Germany, in September 1963, was a memorable occasion. Contributions were received from all continents, although those attending the meeting came only from European countries. Among the 100 papers in the programme, the chief and most-discussed topics were the induction and the breaking of dormancy; the roles of light (mainly effects on the phytochrome system), temperature, atmospheric gases and seed coats; of chemical inhibitors and promoters, foremost among them were the gibberellins; metabolic changes connected with water uptake before and during germination; and the many and intricate interactions between these factors.
The symposium gained much from the wide interpretation of its subject, which included the breaking of the dormancy of vegetative as well as generative organs, and also of bacterial and thallophyte spores.

A paper by Haber (United States) showed that mitosis and photosynthesis can proceed within dormant lettuce seeds, and that dormancy proper is due to a 'block' which specifically prevents elongation of the embryonic axis. Black (Great Britain) discussed the role of the period of unbroken darkness in relation to the dormanoy of seeds of two species, Nemophila insignis, a low-temperature or alternatively a 'short-day' seed, and Betula pubescens, a high-temperature or alternatively a 'long-day' seed. In both cases the photoperiodic sensitivity only becomes apparent over a narrow range of temperature and only so long as the seed coat is intact. In $B$. pubescens the 